\title{
THEORETICAL APPROACH FOR USING SOLAR STILL TO PROVIDE PLANT WATER REQUIREMENT
}

\author{
Abdel-Rahman, G. M.
}

\begin{abstract}
The aim of this research work is to introduce an un- conventional approach to provide fresh water directly from sea water and use it to cover plant water requirements. It comprises theoretical equations to estimate Distilled Water Productivities (DWP) of solar still unit from sea water. On the other hand, another series of equations are used to estimate plant water loss just through transpiration rate. The study was based on six months meteorological data in Jeddah, KSA, from July to December to calculate DWP and plant transpiration rate along this period. These data shown that the maximum value recorded for solar intensity was 825 $\mathrm{W} / \mathrm{m}^{2}$, and the corresponding air temperature was $40.7{ }^{\circ} \mathrm{C}$. The results shown maximum solar still DWP and the corresponding transpiration rate accomplished in September, they were 3196 and $2234 \mathrm{~g} / \mathrm{m}^{2}$ respectively. Meanwhile, the minimum solar still DWP and the corresponding transpiration rate accomplished in September were 1910 and $1254 \mathrm{~g} / \mathrm{m}^{2}$ respectively. Consequently, the obtained results show a possibility to introduce solar still DWP as an un-conventional tool to save plant water requirements terminating traditional irrigation water loss. Therefore, considering the natural sources potential (abundance of solar incidence, very long beaches on seas, gulfs and oceans over Arab World), all support such un-conventional approach for sustainable development programs.
\end{abstract}

\section{INTRODUCTION}

resh water deficit worldwide is one of the major issues and key
factor required for any sustainable development program. Since
most of Arab countries are considered as desert and located in arid and semi-arid regions. Rather, there is sever scarcity of water in the Arab world (mostly below $1000 \mathrm{~m}^{3} /$ capita/year) including Egypt, Libya, Jordon and all Arab peninsula countries.

* Associate prof., Ag. Eng. Dept., Fac. of Ag., Cairo Univ., Cairo, Egypt. 
Considering that, the Arab peninsula area is the only region in the world that doesn't have any rivers or fresh water lakes, but trivial margin of annual precipitation (70-80 mm/year). To the Contrary, it is located on very long coast whether on seas, oceans, gulfs (all are salty water). Meanwhile, there is abundance of solar energy incident available to be used as a renewable energy in this area of the world. Utilizing solar energy in different ways was highlighted by Franz et al. (2009) where they focus on introducing solar power technology as a unique opportunity for competitive, secure and sustainable energy for electricity and seawater desalination in the Middle East and North Africa (MENA) region.

Depending on concentrating solar power (CSP) state of art as a the resources are almost unlimited, and the necessary investments are affordable. The resources exceed by far the present Middle East oil exports and are still untapped. the basic engineering of a first plant for the combined generation of electricity and heat for power, cooling and seawater desalination started in Aqaba, Jordan in 2007. CSP is of vital importance for the MENA (Middle East and North Africa) region, as it is the only available resource that is large and affordable enough to cope with the challenge of growing electricity consumption and increasing shortage of potable water. CSP shares into the energy portfolio. Therefore, MENA governments must establish adequate conditions to initiate proper market CSP technology. One of the recent published papers regarding Arab peninsula region meteorological condition was done by Islam et al. (2009). They collected data on measurement of actual solar radiation in Abu Dhabi (24.43_N, 54.45_E), Arab United Emirates as an example of the region. Global solar radiation and surface temperatures were measured and analyzed for one complete year. Daily and monthly average solar radiation values were calculated from the oneminute average recorded values. The highest daily and monthly mean solar radiation values were 369 and $290 \mathrm{~W} / \mathrm{m}^{2}$, respectively. The highest one-minute average daily solar radiation was $1041 \mathrm{~W} / \mathrm{m}^{2}$. Yearly average daily energy input was $18.48 \mathrm{MJ} / \mathrm{m}^{2} /$ day. Besides the global solar radiation, the daily and monthly average clearness indices along with temperature variations are discussed. The data collected indicate that Abu 
Dhabi has a strong potential for solar energy capture depending on the meteorological data.

Sahooa et al. (2008) have conducted tests with the "solar still" to find out hourly output rate and "still efficiencies" with various test matrices. They found that the efficiency of "solar still" increased by $11 \%$ when capacity of water in the solar basin was raised from 10 to $20 \mathrm{~L}$. Upon suitable modification of the solar basin with appropriate base liner and insulation, this efficiency of the "solar still" is found to further increase by $6 \%$ with a $20 \mathrm{~L}$ basin capacity. On the other hand, Tsilingiris (2009) studied the complex transport phenomena occurring in solar stills with development of the fundamental Dunkle's model. Although it has been based on several simplified assumptions, this model has extensively been employed over the years as a convenient and sufficiently accurate predictive tool for solar stills working under ordinary operating conditions. The comparative presentation of results indicates that although both models are impressively correct for ordinary low temperature operating conditions, where the humid air thermo-physical properties are close to those of dry air. Another study for solar still was conducted by Zaki et al. (1993) they tried to explore improving solar distillation. A model for a simple solar still assisted by an external solar collector is presented. The results show that for coupled stills the fresh water productivity increases as the solar collector area of the assisting device increases. For an ideal system, neglecting the thermal inertia, the yield is linearly dependent upon the solar insolation. The thermal inertia causes a significant drop in the system yield and deviation from linearity. The net efficiency of the coupled system is higher than that of a similar simple still by a value that depends mainly upon the system configuration and independent of the meteorological conditions.

Consequently, such huge amount of renewable and available solar energy (SE) could be used in desalinating sea water for agricultural purposes. Therefore, predicted amount of produced distilled water (PDW), considered as precious fresh water should be used to grow plant. Looking to the ways of water loss in agricultural activities are: runoff, deep percolation, free evaporation from the wet soil around plant and transpiration through stomata. The rational use of these DSW should be 
done through preciously and accurate watering system for agricultural production such as confined mulch plantation, hydroponic, earoponic or even nutrient film technique (NFT). These approaches of plantation should eliminate all the previously mentioned water losses except plant transpiration.

Consequently, the main purpose of the current research work is to explore if the solar still DWP is enough to cover the calculated plant transpiration as the only value of plant water requirement (PWR), with no water loss.

One of the relevant researches to the issue of PWR, which should be estimated based on the meteorological factors was done by AbdelRahman (2001), where he focused on the leaf temperature as a major factor affecting transpiration rate of an ornamental plant (New Guinea Impatiens cv. Antares). Two different ways were used to measure leaf temperature continuously; two infrared sensors (IR) precision and two tiny-insulated, thermocouples. Other environmental factors such as; air and leaf temperature, incident solar radiation, air velocity and air relative humidity were also recorded. The results showed that the TC sensors were always $2-3{ }^{\circ} \mathrm{C}$ higher than the IR. The maximum transpiration rates were (400 and $500 \mathrm{~g} / \mathrm{m}^{2} . \mathrm{h}$ ) to the corresponding leaf measured by both IR and TC respectively.

Recently, another research done by Jose et al. (2008) to estimate the relationship between quantity of the local crop production to the corresponding irrigation. They figure out a very important relation of biomass produced and adequate irrigation management strategies. Also this study evaluated the effect of irrigation applied with subsurface drip irrigation on field corn (Zea mays L.) evapotranspiration (ETc), yield, water use efficiencies (WUE $=$ yield/ETc, and IWUE $=$ yield/irrigation), and dry matter production in the semiarid climate of west central Nebraska. Eight treatments were imposed with irrigation amounts ranging from 53 to $356 \mathrm{~mm}$ in 2005 and from 22 to $226 \mathrm{~mm}$ in 2006. Treatments resulted in seasonal ETc of 580-663 mm and 466-656 mm in 2005 and 2006 , respectively. Yields among treatments differed by as much as $22 \%$ in 2005 and $52 \%$ in 2006. In both seasons, irrigation significantly affected yields, which increased with irrigation up to a point where irrigation 
became excessive. On the average, the grain accounted for the majority of the above-ground plant dry mass $(59 \%)$, followed by the stover $(33 \%)$ and the cob (8\%). The dry mass of the plant and that of each plant component tended to increase with seasonal ETc. Another important physiological process for plant which is photosynthesis was studied by Jose et al. (2008). The main aim of their research was to compare the photosynthetic responses of two species of Prosopis, (algarrobo) and Prosopis (tamarugo) plant subjected to heat and water stresses, to determine how heat shock or water deficit, either individually or combined, affect the photosynthesis of these two species. The photosynthetic rates expressed as a function of photon flow density (PFD) were determined by the $\mathrm{O}_{2}$ liberated, in seedlings of tamarugo and algarrobo subjected to two water potentials: 0.3 MPa and 2.5 MPa and to three temperatures: 25,35 and $40{ }^{\circ} \mathrm{C}$. The maximum photosynthetic rates decreased with temperature in both species and with water deficit in algarrobo. At $40{ }^{\circ} \mathrm{C}$ and $2.5 \mathrm{MPa}$, the photosynthetic rate of algarrobo fell to $72 \%$ of that of tamarugo. The quantum yield decreased in algarrobo with temperature and water deficit and it was reduced by $50 \%$ when the conditions were $40{ }^{\circ} \mathrm{C}$ and $2.5 \mathrm{MPa}$. Water deficit reduced the amount of RUBISCO in both species. The results of this work support the conclusion that in both Prosopis species, the interaction between high temperature and water deficit affects photosynthesis responses greater than each individual stress.

Penmann- Monteith model was used by Lovelli et al. (2008) aimed to propose an easy-to-use methodology for irrigation scheduling, to assess the values Leaf area index (LAI) during the growing cycle and thus for canopy resistance assessment. In muskmelon crop, grown with and without plastic film mulching, canopy resistance was measured by $\mathrm{P}-\mathrm{M}$ formula inversion. In particular, in the mulched crop, the "one-step", approach of $\mathrm{P}-\mathrm{M}$ overestimates water use only by $4 \%$, while the "two steps" approach underestimates water use by $17 \%$. Despite both the methodologies proposed for LAI calculation and the Monteith model to assess canopy resistance extremely simplify more complex processes. They were able to give a good accuracy to assess muskmelon water use by the P-M “one-step" equation. 
One of the reliable and economically feasible method to control water loss was conducted by Debashis et al. (2008) where they tested mulching as one of the important agronomic practices in conserving the soil moisture and modifying the soil physical environment. They established field experiments during winter seasons of 2004-2005 and 2005-2006 in a sandy loam soil. They aimed to evaluate the soil and plant water status in wheat under synthetic (transparent and black polyethylene) and organic (rice husk) mulches with limited irrigation and compared with adequate irrigation with no mulch (conventional practices by the farmers). Though all the mulch treatments improved the soil moisture status. The plant water status, as evaluated by relative water content and leaf water potential were favorable under RH. Specific leaf weight, root length density and dry biomass were also greater in this treatment. This produced comparable yield with less water use, enhancing the water use efficiency. Therefore, it may be concluded that under limited irrigation condition, RH mulching will be beneficial for wheat as it is able to maintain better soil and plant water status, leading to higher grain yield and enhanced water use efficiency.

Fiona et al. (2008) studied the halophyte forage shrub, Atriplex lentiformis (quailbush), was irrigated with brine from a reverse-osmosis (RO) water treatment plant in an agricultural district in Marana, Arizona, in the Sonoran Desert, U.S. Small transplants were installed in large, outdoor drainage lysimeters and drip-irrigated with RO concentrate, on a schedule designed to deliver 1.5 times the reference evapotranspiration (ETo) on a daily basis, as determined by an on-site micrometeorological station. Water consumption was measured by a water-balance approach over an annual cycle and by measuring sap flow with heat-balance sensors over a 28-day period in August 2008. Over this annual cycle, biomass yield was $1.62 \mathrm{~kg} \mathrm{~m}^{-2}$ and the average water consumption during the growing season was 1.55 times ETo, similar to values for highbiomass crops such as alfalfa. The drainage fraction (water that exited lysimeters) was only $5 \%$ of the total input (irrigation plus precipitation) over the study. Rates of transpiration measured by sap flow sensors were closely coupled to both solar radiation and atmospheric water demand on hourly and daily time steps. Stomatal conductance was high throughout 
the day and coupled to diurnal solar radiation. The high yield and consumptive water use by A. lentiformis makes it a good candidate for the reuse of industrial or agricultural brines in arid-zone irrigation districts.

\section{MATERIAL AND METHODS}

The current research work was depending on using data been published by research conducted at Faculty of Engineering, King Abdul-Aziz University, Jeddah, Saudi Arabia Kingdom. This research was done by Zaki et al. (1994) which was consisted of solar still units. The solar still DWP coming from sea water through this solar still was estimated by series of equations This type of basin solar still was shown in fig. (1).

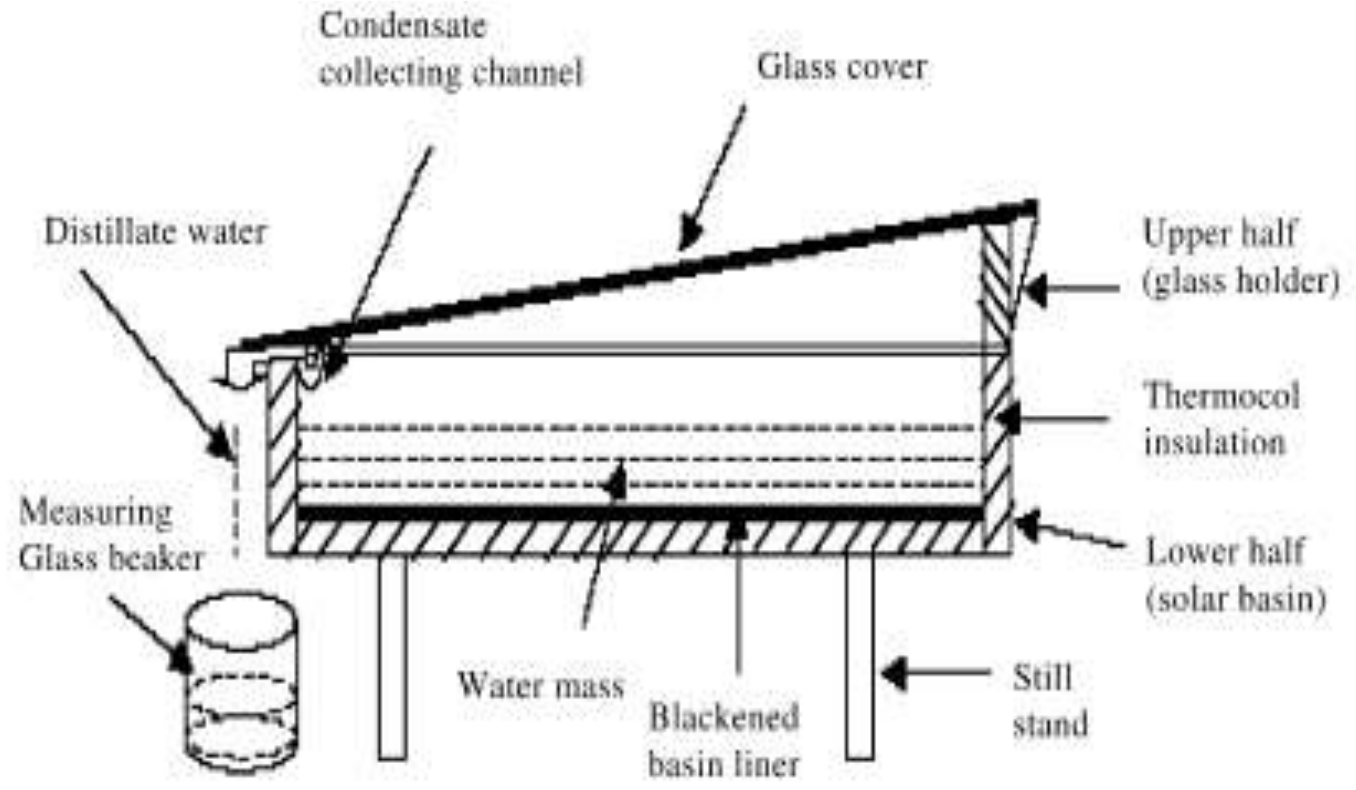

Fig. (1): Simple structure of basin solar still unit.

\section{1- Energy Balance equation to determine solar still yield:-}

The solar still equations were mentioned by Zaki et al. (1993) where they stated that the still productivity could be estimated after a certain period accumulates distilled water productivity (DWP) during this period, therefore 


$$
D W=\frac{\int_{0}^{t} h_{e}\left(T_{w}-T_{c}\right) d t}{L H_{v}}
$$

Where:-

$\mathrm{DW}$ is distilled water quantity, $\mathrm{t}$ is taken as one hour during which time dependency of he and $\left(T_{w}-T_{c}\right), \mathrm{h}_{\mathrm{e}}$ is heat transfer coefficient for evaporation, $T_{w}$ and $T_{c}$ are water and still cover temperatures respectively, $L H_{v}$ is latent heat of evaporation.

The daily yield of a still is summation of the $D W$ to estimate the productivity over 24 hour period as follows;

$$
D W P=\sum_{j=1}^{24} D W_{j}
$$

\section{2- Energy balance equations to estimate transpiration}

On the other hand, plant water requirements will be estimated through considering the ambient conditions on plant micro-climate stage to compute transpiration rate. Taking into account that, the irrigation system used should be accurate enough not to allow the conventional water loss such as (runoff, deep percolation and evaporation from wet soil). Therefore, the only allowed water use part to be refilled by irrigation system and considered as an actual plant water requirement is transpiration value. A simple model was applied to estimate transpiration rate for greenhouse canopy. Plant should be growing under greenhouse conditions to control the meteorological factors affecting transpiration calculation.

The transpiration has been computed using the following sequence of empirical equations:-

$$
r_{i n t}=685.5 r_{\Delta p} r_{l} \quad r_{c o 2}
$$

where: $r_{i n t}$ is the internal leaf resistance $(\mathrm{s} / \mathrm{m})$

$\mathrm{r}_{\Delta \mathrm{p}}$ is the leaf resistance for vapor pressure deficit.

$$
\begin{aligned}
& \mathrm{r}_{\Delta \mathrm{p}}=\text { minimum of }\left(3.8 \text { and }\left(1+\left(5.2 \times 10^{-6}\right) \Delta \mathrm{p}^{2}\right)\right. \\
& \text { While, } \Delta \mathrm{p} \text { is the vapor pressure deficit }(\mathrm{Pa}) .
\end{aligned}
$$

$r_{l}$ was found empirically to be $(390 \mathrm{~s} / \mathrm{m})$. 


$$
r_{c o}{ }^{2}=1+1.11 \times 10^{-11}(\mathrm{C}-200)^{2},
$$

where $r_{c o}{ }^{2}, \mathrm{C}$ is carbon dioxide concentration in the canopy boundary, and the leaf resistance for carbon dioxide considered to be equal $(1 \mathrm{~s} / \mathrm{m})$, it can be neglected mathematically,

$$
r_{e x t}=\frac{1174}{\left[L\left(\left|T_{c}-T_{u}\right|\right)+207 U^{2}\right]^{0.25}}
$$

Where $r_{\text {ext }}$ is the external leaf resistance $(\mathrm{s} / \mathrm{m})$, and $\mathrm{U}$ is air velocity in $\mathrm{cm} / \mathrm{s}, L$ is characteristic dimension considered to be 1 and $7 \mathrm{~cm}$ air velocity in the greenhouse had been reported by both Stanghellini (1987) and De Zwart (1996) to be between (0.04 and $0.2 \mathrm{~m} / \mathrm{s}) .\left|T_{c}-T_{u}\right|$ is the absolute temperature difference between canopy and air. The same approach of Kempkes et al. (2000) estimated the transpiration as follows:

$$
Q c=2 L c \quad \rho \quad \mathrm{C}_{\mathrm{p}} \Delta p \quad\left(\gamma\left(\mathrm{r}_{\mathrm{int}}+r_{e x t}\right)\right)^{-1}
$$

Considering the following physical constant values; $Q c$ is the latent heat flux density by transpired water $\left(\mathrm{W} / \mathrm{m}^{2}\right), L c$ is the leaf area index $\left(\mathrm{m}^{2} / \mathrm{m}^{2}\right)$, $\gamma$ is the psychometric constant (considered as $66 \mathrm{~Pa} /{ }^{\circ} \mathrm{C}$.), air density $(\rho)$ $=1.185 \mathrm{~kg} / \mathrm{m}^{3}$ at $300 \mathrm{~K}$, specific heat of air $\left(C_{p}\right)=1003 \mathrm{~J} / \mathrm{kg} . \mathrm{K}$. Heat vaporization conversion constant $\left(\mathrm{C}_{\mathrm{vp}}\right)$ was taken $=2.6 \mathrm{X} 10^{-5} \mathrm{~g} \cdot \mathrm{W}^{-1}$. Consequently, in this research the previously mentioned latent heat equation $(Q c)$ can be converted into another simple equation for transpiration $(T p)$ rate directly and to become as:

$$
T p=Q c . C_{v p}
$$

where $T p$ is the expected transpiration rate in g.m. ${ }^{-2}$

\section{RESULTS AND DISCUSSIONS}

As mentioned before, the main purpose of current research is to explore if the solar still DWP is enough to cover the calculated plant transpiration as the only value of plant water requirement (PWR), considering no water loss. Assuming the plant production with solar still DWP should be watering throughout a precise and confined watering system. The recommended plantation system should be under fully controlled greenhouse environment with confined mulching, hydroponic, nutrient 
film technique (NFT) or aeroponic to avoid any water loss. Therefore the discussion will focus on adequacy of DWP to the actual plant water need as transpiration rate. The monthly average of both DWP and transpiration rate.

\section{1- Adequacy of distilled water productivities (DWP) to plant} transpiration rate:

It was clear that DWP values through July, as shown in fig. (2), had a harmony fluctuation along the daily average values of solar intensity, DWP and transpiration rate.

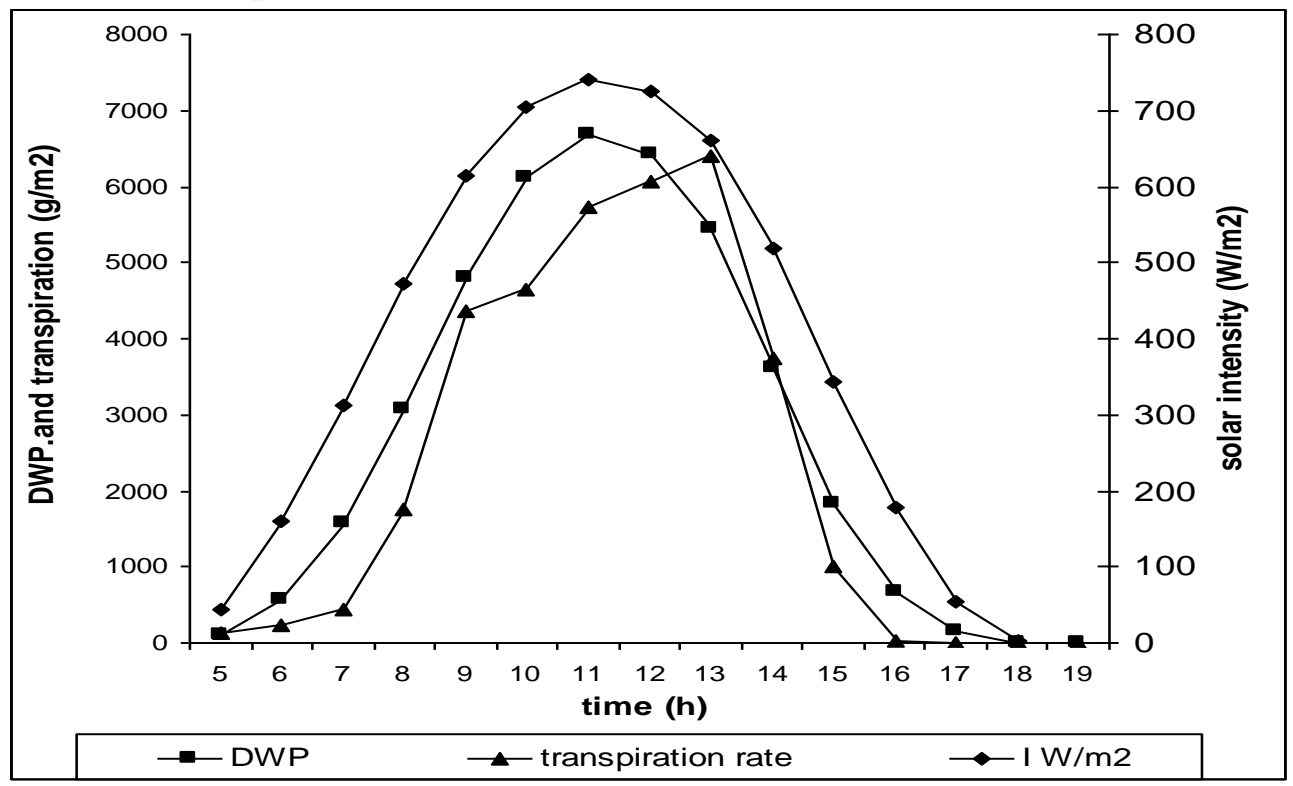

Fig (2): Solar intensity, air temperature and solar still productivity in July

The same trend was noticed along August month as shown in fig. (3). Also, it was notice that transpiration rate was always below the DWP rate. This trend was noticed along most of the experiment period. That was a good sign to support the idea behind this research for using solar still and its DWP to watering greenhouse plantation. However, the maximum average of DWP value was accomplished in fig.(4) of September. That was due to the maximum solar intensity among the same period as shown in fig. (4). Meanwhile the maximum average value was found 
corresponding to the same period due to the same reason (highest solar intensity).

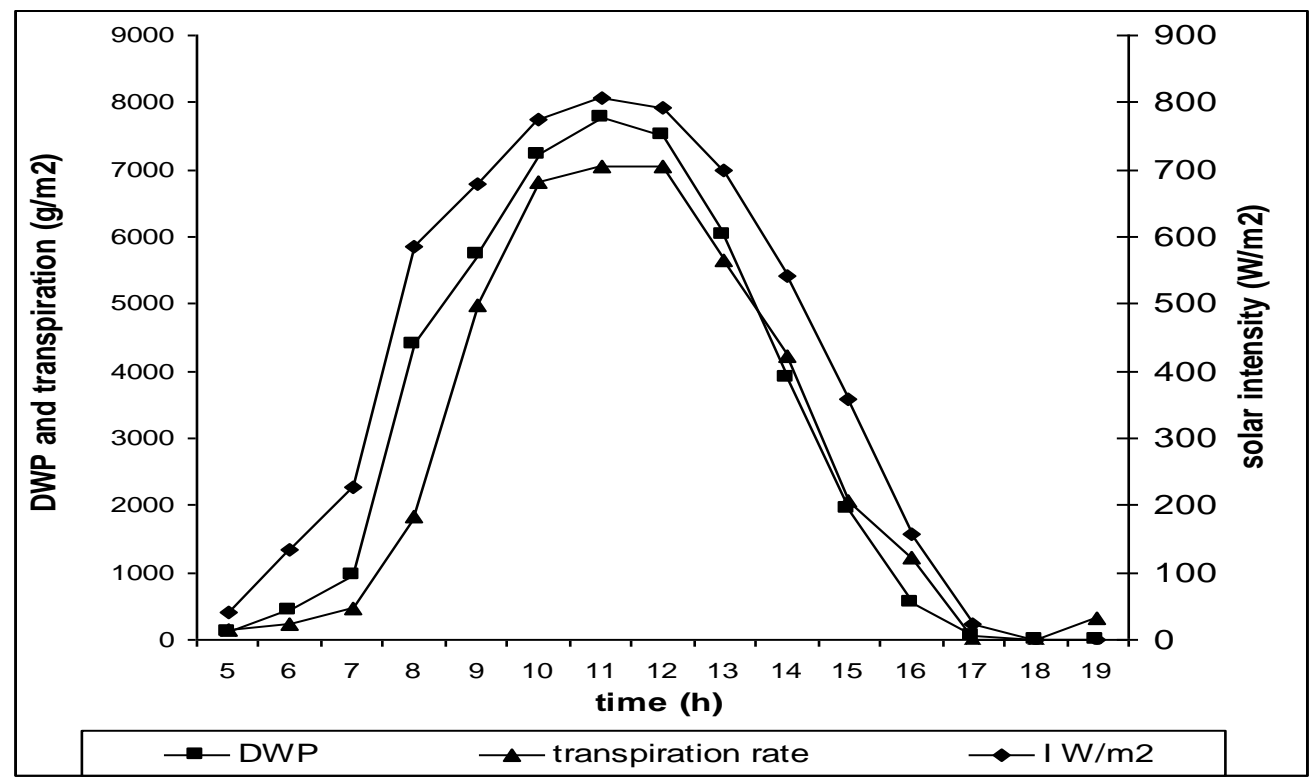

Fig (3): Solar intensity, air temperature and solar still productivity in Aug.

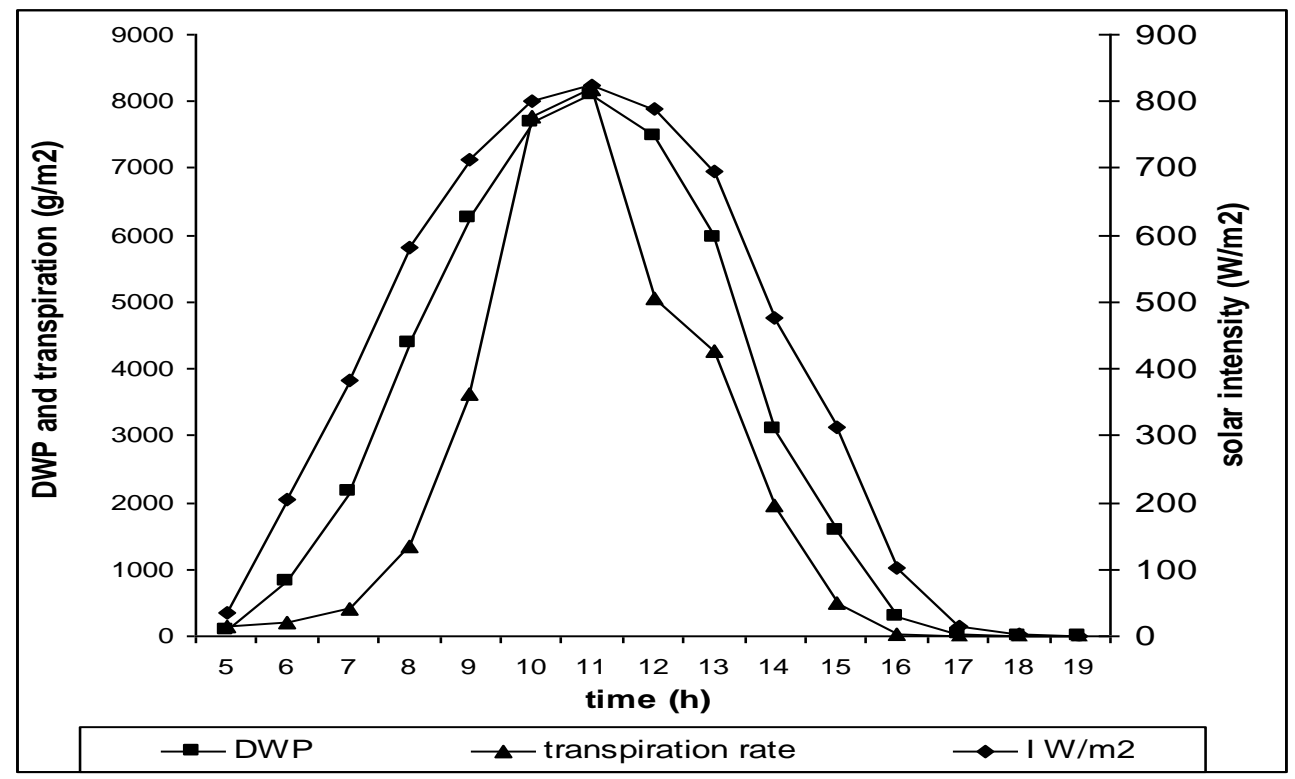

Fig (4): Solar intensity, air temperature and solar still productivity in Sept. 
The results shown that the maximum average value of DWP was achieved on the mid-day time along the whole period of the experiment. It was noticeable that the gap between DWP and transpiration curve decreases by the end of the day comparing to the beginning of the day. That was due to the effect of heat stress on the plant transpiration rate, as it shown in figures 5, 6 and 7.

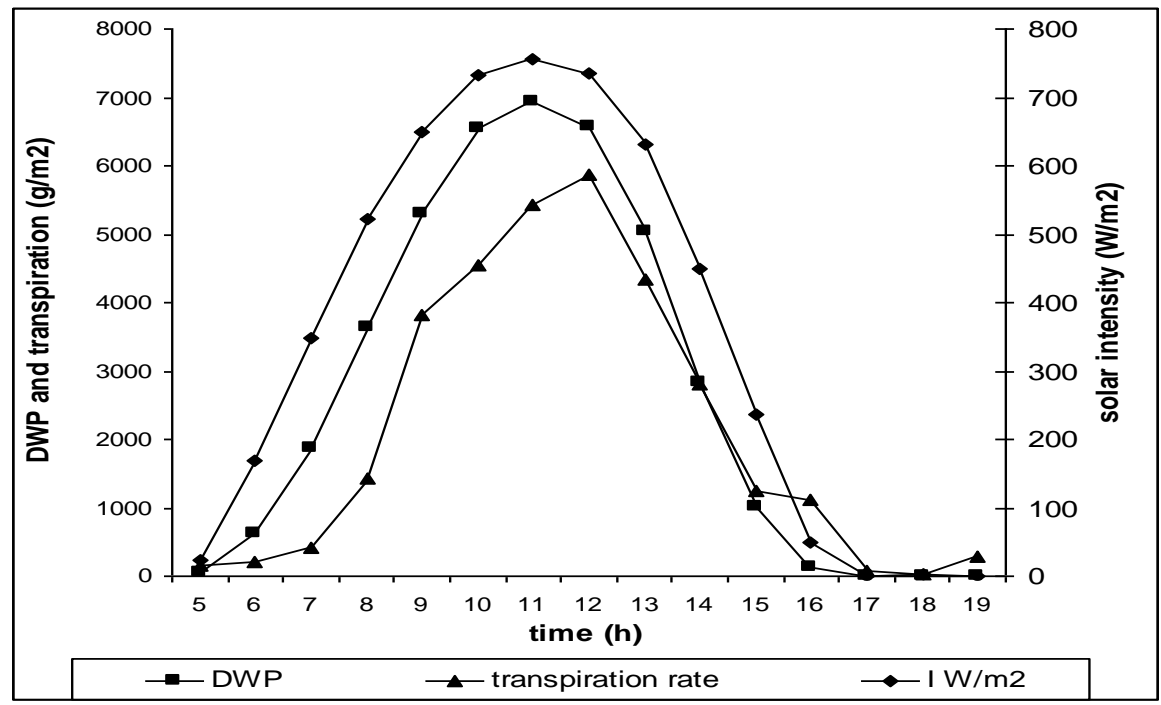

Fig (5): Solar intensity, air temperature and solar still productivity in Oct.

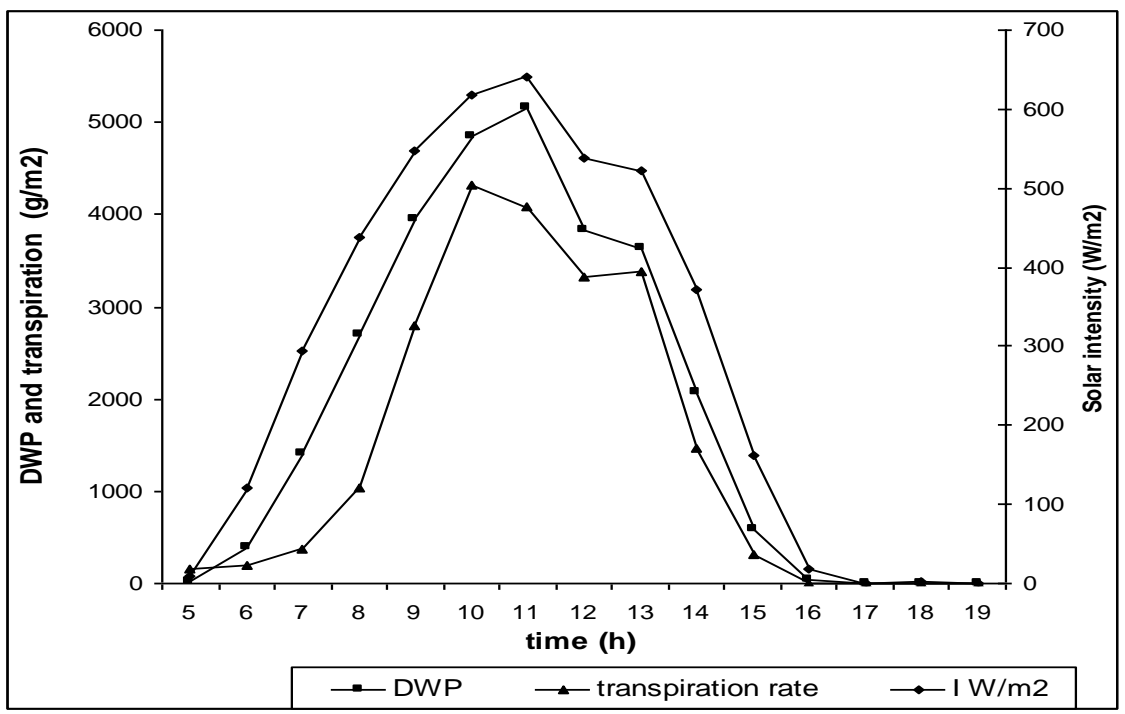

Fig (6): Solar intensity, air temperature and solar still productivity in Nov. 
Considering that the key factor regarding DWP and transpiration rate is temperature, which mean solar intensity. Therefore, the peak of the DWP and transpiration rate were achieved by med-day (between time 12-14) as shown in most figures. Since cloudiness affects negatively the rate of solar intensity. Consequently, as the winter time came, the cloudiness dominated and control the solar intensity. This definitely affect the average value of DWP as shown in fig. (6).

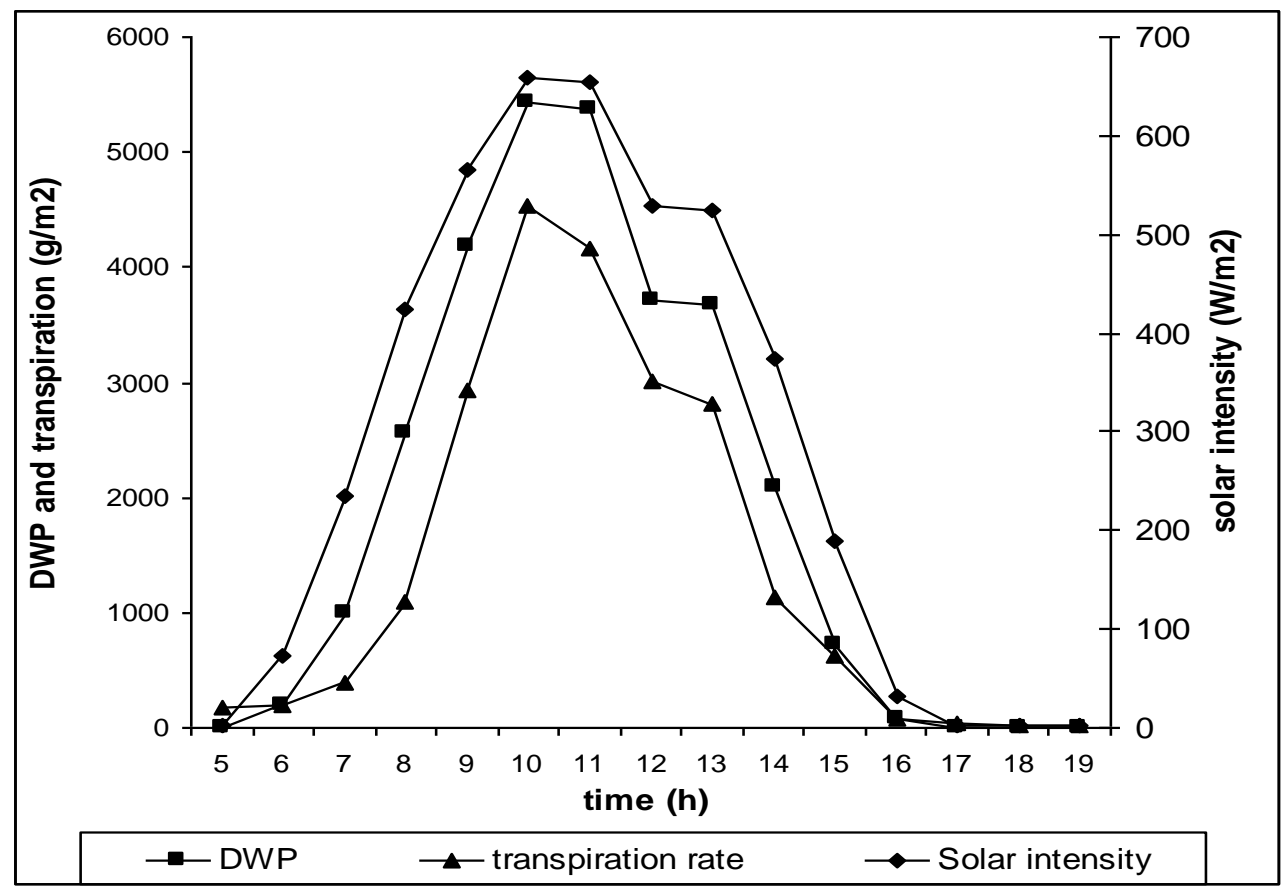

Fig (7): Solar intensity, transpiration rate and solar still productivity in Dec.

Therefore the minimum average value of DWP and corresponding transpiration rate (about 1900 and $1400 \mathrm{~g} / \mathrm{m}^{2}$ respectively) recorded were achieved through months November and December as shown in Fig. (6) and (7).

\section{2- The average monthly values of DWP and transpiration rates:}

It was quite clear that average values of both DWP and transpiration rates along the entire six month period data that transpiration rates were always 
below the rate of DWP. Also as shown in fig.(8), however DWP was function of solar intensity. The same trend was noticed for transpiration rate and harmonically fluctuated with DWP. That could give strong support to the idea of using solar still units to cover plant water requirements considering an accurate and precise watering system under greenhouse conditions.

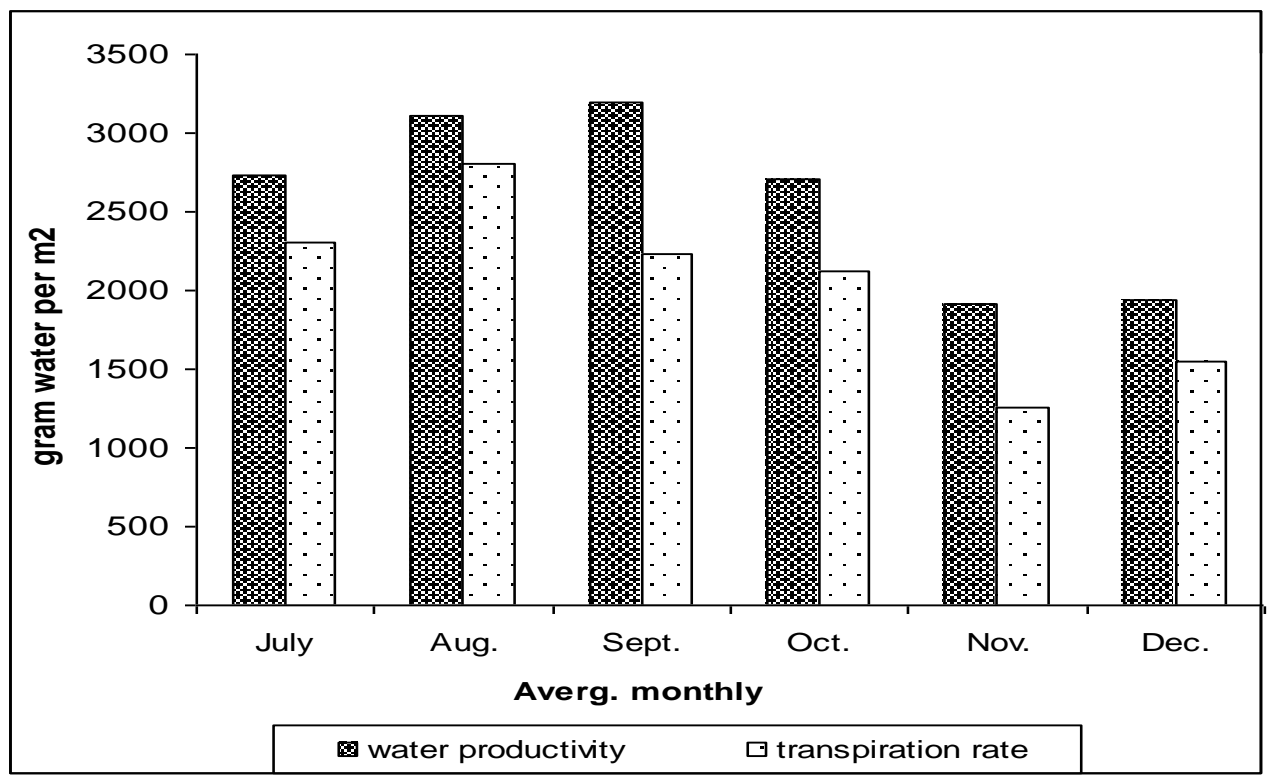

Fig (8): Average monthly value of DWP and transpiration rate.

\section{REFERENCES}

Abdel-Rahman, G. M. 2001. Contact and non-contact sensing of new guinea impatiens leaf temperature on transpiration Rate. Misr. J. Ag. Eng., 18 (3): 821-831.

Debashis C., S. Nagarajan, P. Aggarwal, V. K. Gupta, R. K. Tomar, R. N. Garg, R. N. Sahoo, A. Sarkar, U. K. Chopra, K. S. S. Sarma and N. Kalra. 2008. Effect of mulching on soil and plant water status, and the growth and yield of wheat (Triticum aestivum L.) in a semi-arid environment. J. Ag. Water Management, No. 95, pp. $1323-1334$

Fiona L. J., M. Yoklic, K. Morino, P. Brown, R. Seaman and E. P. Glenn. 2008. Consumptive water use and stomatal conductance of 
Atriplex lentiformis irrigated with industrial brine in a desert irrigation district. On line Journal of Agriculture and Forest Meteorology, AGMET-4013; No of Pages 14.

Franz T., H. Müller-Steinhagena, J. Kernb, J. Scharfec, M. Kabaritid and A. Al-Taherd. 2009. Technologies for large scale seawater desalination using concentrated solar radiation. J. Desalination No. $235,: 33-43$

Jose, O. P., D. D. Tarkalson, S. Irmak, D. Davison and J. L. Petersen. 2008. Effect of irrigation amounts applied with subsurface drip irrigation on corn evapotranspiration, yield, water use efficiency, and dry matter production in a semiarid climate. J. Ag. Water Management, pp 895 - 908.

Jose D., M. Pinto and L. Cardemil. 2008. Effects of water stress and high temperature on photosynthetic rates of two species of prosopis. J. Photochemistry and Photobiology B: Biology 92 : 67-76.

Islam, M. D., I. Kubo, M. Ohadi and A. A. Alili. 2009. Measurement of solar energy radiation in Abu Dhabi, UAE. Applied Energy 86, 511-515.

Lovelli S., M. Perniola, M. Arcieri, A. R. Rivelli and T. DiTommaso. 2008. Water use assessment in muskmelon by the Penman-Monteith “one-step" approach. J. Ag. Water Management, 95: 1153 - 1160.

Sahooa B. B., N. Sahoob, P. Mahantab, L. Borboraa, P. Kalitaa and U. K. Sahab, 2008. Performance assessment of a solar still using blackened surface and thermocol insulation. Technical Note, Journal of Renewable Energy 33 : 1703-1708.

Tsilingiris P.T. 2009. Analysis of the heat and mass transfer processes in solar stills-The validation of a model. J. Solar Energy 83: 420-431.

Zaki G. M., M. Abdulhaiy, A. Radhwan and O. Balbeid. 1993. Analysis of assisted coupled solar stills. Solar Energy, 51 (4): $277-$ 288. 


\section{الملذص العربي \\ مدخل نظرى لاستخدام وحدات التحلية الثمسية للمياه لتوفير الاحتياجات المائية للنبات}

\section{جمال منصور عبد الرحمن}

يهدف هذا البحثِ الى تقديم مدخل نظرى لاسلوب غير تقليدى لانتاج الماء العذبِ مباشرة من مايٍ البحر، و إستخدامها لتغطية متطلبات النبات المائية. ويتلخص هذا المدخل في بعض المض المعادلات النظرية للتنبؤ بمعدلات تقطير ماء البحر و إنتاج الماءِ العذب مباشرة اعتمادآ على استغلال الطاقة الثمسية. وعلى الجانب الآخر، هنالك سلسلة أخرى من المعادلات استخدمت للتنبؤ بكمية الماءِ

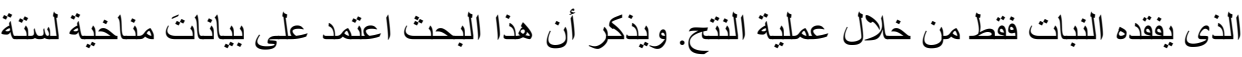

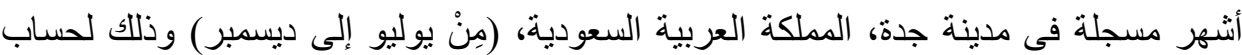
كمية الما المقطر المنتجة بوحدات التحلية الثمسية والتى يرمز لها فى البحث (DWP).

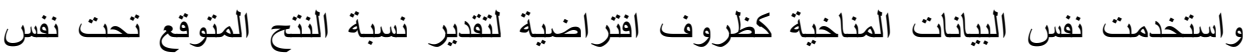
الظروف ولنفس الفترةِ الزمنية المشار اليها. وقد أوضحت هذه البياناتِ بأن الحد الأقصىى للقيمةً

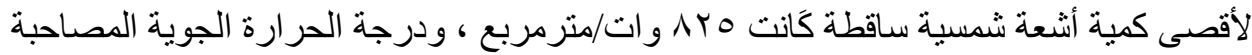

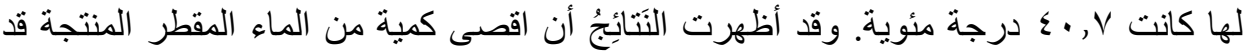

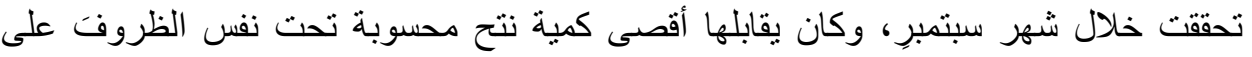

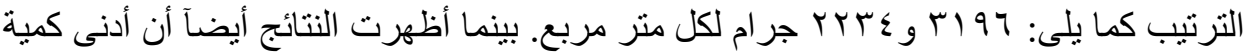

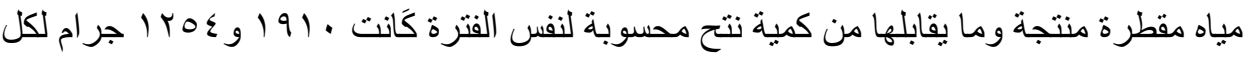

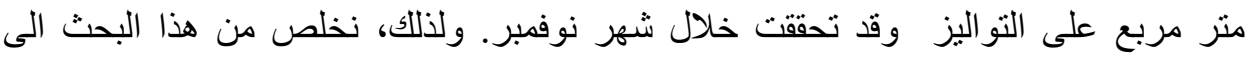

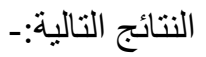

ا - إمكانية استغلال وحدات التحلية الثمسية كأسلوب غير تقليدي لتَوفير احتياجات النبات

المائية بشرط إتباع إجراءات ونظام رى محكم (لا تحدث خلاله الفواقد المائية

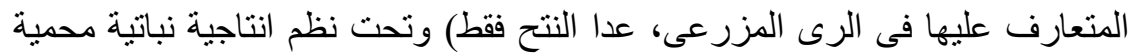

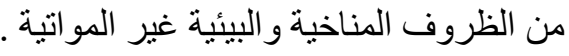

r- باعتبار الإمكانيةً و المصادرِ الطبيعية فى منطقة الوطن العربهى (وفرةٍ الطاقة الثمسية،

شواطئ طويلة جداً على البحارِ وخلجانِ ومحيطات للعالٍِ العربي) التي تدعم مثل هذه الإنه

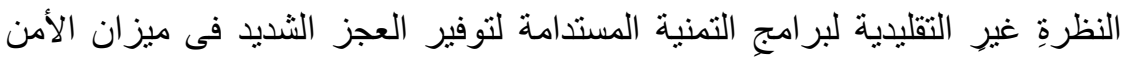

الغذائى لأغلب البلدان العربية.

* استاذ مساعد ـ قسم الهندسة الزر اعية ـ كلية الزراعة ـ جامعة القاهرة. 